\title{
POLLUTION EFFECT OF FOOD AND BEVERAGES EFFLUENTS ON THE ALARO RIVER IN IBADAN CITY, NIGERIA
}

\author{
Ayodele Rotimi Ipeaiyeda ${ }^{*}$ and Percy Chuks Onianwa \\ Department of Chemistry, University of Ibadan, Ibadan, Nigeria
}

(Received March 23, 2010; revised October 2, 2010)

\begin{abstract}
The main course of water pollution in the Alaro river is the direct discharge of food and beverages processing effluents. The impact of such effluents on the water quality was studied in detail by monitoring selected physicochemical parameters monthly between January 2003 and December 2007. The combined effluent was equally monitored. This study provided a detailed data on the quality of the effluent at the designated discharge point, upstream and downstream locations. The background levels of $250 \pm 4 \mathrm{mg} / \mathrm{L}$ (TS), $178 \pm 3 \mathrm{mg} / \mathrm{L}$ (TDS), $6.5 \pm 0.2$ FTU (turbidity), $132 \pm 5 \mathrm{mg} / \mathrm{L}$ (total hardness), $157 \pm 4 \mathrm{mg} / \mathrm{L}\left(\mathrm{Cl}^{-}\right), 157 \pm 0.3 \mathrm{mg} / \mathrm{L}\left(\mathrm{NO}_{3}^{-}\right)$, $9.65 \pm 0.39 \mathrm{mg} / \mathrm{L}\left(\mathrm{SO}_{4}{ }^{2-}\right), 2.12 \pm 0.01 \mathrm{mg} / \mathrm{L}(\mathrm{BOD}), 103 \pm 5 \mathrm{mg} / \mathrm{L}(\mathrm{COD}), 0.54 \pm 0.02 \mathrm{mg} / \mathrm{L}(\mathrm{Ni}), 0.59 \pm 0.02 \mathrm{mg} / \mathrm{L}$ $(\mathrm{Zn}), 0.25 \pm 0.02 \mathrm{mg} / \mathrm{L}(\mathrm{Cr})$ and $0.17 \pm 0.02 \mathrm{mg} / \mathrm{L}(\mathrm{Pb})$. The overall levels of these water quality indicators went up after the effluent discharge point. Overall, the effluent contained contaminants whose levels exceeded the effluent guideline for discharge into surface water and drinking water criteria. Hence, water pollution of the Alaro river is very evident.
\end{abstract}

KEY WORDS: Water quality, River Alaro, Pollution, Industrial effluent

\section{INTRODUCTION}

Daily, large quantities of industrial effluents are discharged, virtually untreated into the rivers. An estimated $80 \%$ of industrial effluents flow directly into the rivers through ditches, shallow pits, gutters and trenches [1]. Some of the pollutants encountered in municipal borne water supply originate from industrial effluents which are deliberately produced and released into water bodies. Industrial effluent is known to contain contaminants and its disposal to water bodies without proper treatment may results to exposure of humans to such contaminants [2]. With increasing scarcity of treated public water supply, fresh river water has become the alternative source for drinking. The World Health Organisation (WHO) recognizes the need to ensure the safety of most water bodies that serve as sources of drinking water supplies to the public. Hence routine monitoring of water quality of such useful water bodies is expedient as required by WHO.

Water, like food, is a vehicle for the transmission of many agents of disease and continues to cause significant outbreak of diseases in developed and developing countries world-wide. It was identified as the source of, among others, the most outbreaks of Escherichia coli in Canada to date [3]. A Cryptosporidium outbreak in Milwaukee, Wisconsin, USA in 1993, affected approximately 400,000 consumers and caused 54 deaths [4, 5]. In 1970, a cholera epidemic in Jerusalem was traced back to the consumption of salad vegetables irrigated with raw wastewater [6]. Similar outbreak of cholera epidemic and other water related diseases were noticed in Nigeria on several occasions [7, 8]. Contaminated river water used for irrigation had been associated with various water borne diseases $[9,10,11]$. Despite these prevalent outbreaks the pressure on the world's water resources is growing. Water usage in North America increased by approximately $800 \%$ from 1900 to 1995 while global water use in 2000 was estimated to be nearly three times than in 1950 [12]. As demand increases, pollution of surface water has further reduced the availability of fresh river water for intended purposes.

\footnotetext{
*Corresponding author. E-mail: ayosade2003@yahoo.com
} 
In Nigeria, non-availability of treated public water supply has led the populace to optimise the riverwater use for drinking and irrigating agricultural lands purposes. The situation is of great concern in Ibadan city where most industries are heavily concentrated at Oluyole Industrial Estate. The Alaro river that traversed the estate has been a receptacle for effluent flowing from food and beverage processing plants that are located at the estate. The deterioration of the river is inevitable since the effluent received on a daily basis constitutes a considerable factor of pollution. At a distance downstream farther from the study area, the Alaro river, being one of the major rivers in Ibadan, is relied on as an alternative for the scarce pipe borne water for domestic and irrigating agricultural lands. Given the unique beneficial purposes of the Alaro riverwater, regular monitoring of the water quality of such river should be conducted and the outcome is to be of great significance to the World Health Organisation for an effective environmental planning and management of rivers around the globe. It is hoped that this will lead to a more efficient prevention of adverse health effect associated with the consumption or use of such riverwater.

Therefore, the goal of this study was to assess the water quality of the Alaro river upstream and downstream of the discharge point of effluent flowing from food and beverages industries. The essence was to verify whether the riverwater has undergone self purification as to recover from the impact of received pollutants to a certain tolerable limit for drinking such water and using it for other beneficial purposes. The level of contamination of the river was established by determining the quality of the effluent at the discharge point, upstream and downstream water quality. In addition, seasonal trend in water quality of the river was investigated. Another objective was that this study will provide baseline data against which future studies can be compared.

\section{EXPERIMENTAL}

\section{Description of sampling site and study design}

Oluyole industrial estate is situated in a densely populated part of Ibadan city, Nigeria. Among many polluting industries located at the estate, only food and beverage industries discharge effluents directly into the Alaro river. Biscuits and drinks are the major products of these industries. Other industries at the estate are sparsely located far away from the reach of the river channel for it to receive their effluents. There is a central drainage which receives effluents directly from the two industries and channels it as a combined effluent into the Alaro river.

The study was designed such that the hydrological profile of the watercourse of the river, physico-chemical quality of the effluent at the discharge point and water quality of the river at upstream and downstream locations were investigated. The whole length of the Alaro river was divided into two segments namely: the upstream and downstream zones. The discharge point at which effluent entered the water-course formed the basis for segmentation and was designated as the junction $(\mathrm{JN})$. This junction, therefore, distinguished the upstream zone from downstream zone. The river was monitored to about $300 \mathrm{~m}$ upstream and $500 \mathrm{~m}$ downstream. Sampling points were located along these two extreme zones.

\section{Sampling points}

The location of sampling points upstream and downstream of the effluent discharge point was done randomly. Eight sampling points were located along the river course in addition to one point along the central drainage. The descriptions of the sampling points were, depicted in Figure 1 are as follows: (i) two sampling points located at the upstream were designated as U-1 $(150 \mathrm{~m})$ and U-2 $(300 \mathrm{~m})$, upstream locations were regarded as the control point; (ii) one sampling point was located along the drainage that channelled the effluent into the river, this 
point was regarded as the discharge point through which the effluent entered the river and it was designated as E-1 (25 m); (iii) one sampling point was located at the junction where the effluent flowed into the river, and it was referred to as $\mathrm{JN}(0 \mathrm{~m})$; and (iv) five sampling points were located downstream and designated as D-1 (100 m), D-2 (200 m), D-3 (300 m), D-4 (400 m) and D-5 (500 m).

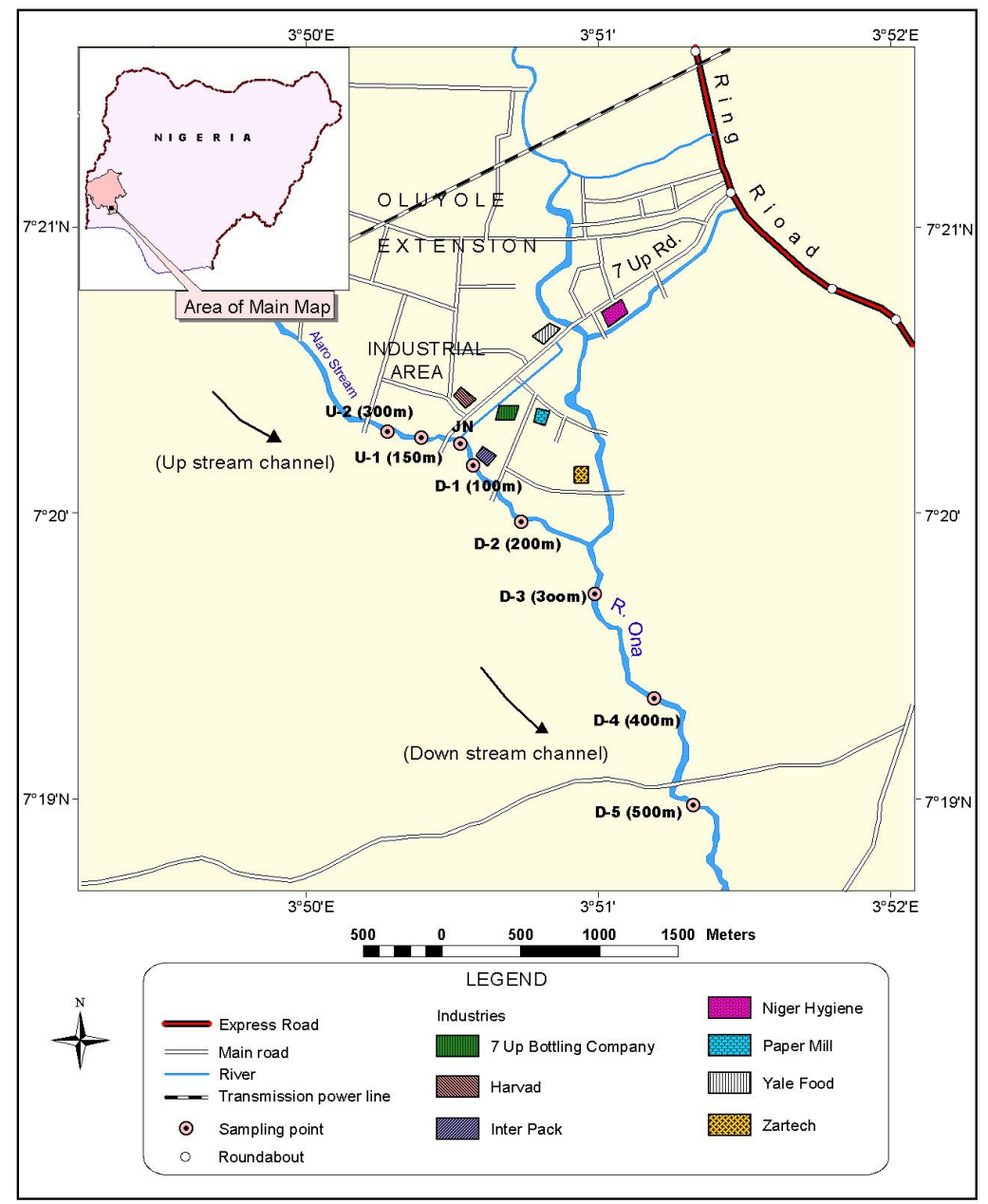

Figure 1. Map of Oluyole industrial estate showing sampling points along the Alaro river.

\section{Sampling and chemical analysis}

Water samples were collected each month at eight points along the river together with the effluent at the discharge point. This was done with a view to monitor the quality of the effluent and its impact annually on the river water quality during the study period (January 2003 to December 2007). The sampling was undertaken by first rinsing the clean plastic bottles with the river water before collecting the samples. The bottles were then stored in an ice chest. Separate

Bull. Chem. Soc. Ethiop. 2011, 25(3) 
samples collected for heavy metal analysis were fixed in the field with $3 \mathrm{~mL}$ Analar grade nitric acid per litre of sample.

All laboratory analyses were carried out following the standard protocols [13, 14]. The water velocity of the river was measured at each of the sampling points using the calibrated water current meter (Valepost BFM002) following the area-velocity method [15]. Water temperature was measured on the site using a mercury thermometer. The samples were analysed for the following parameters using specific standard methods: turbidity (turbidimetry), alkalinity (acid-base titrimetry), total solids-TS, total suspended solids-TSS (gravimetry), chloride- $\mathrm{Cl}^{-}$ (mercurimetric titration), nitrate- $\mathrm{NO}_{3}{ }^{-}$(phenodisulphonic acid colorimeter method), sulphate$\mathrm{SO}_{4}{ }^{2-}$ (turbidimetry), phosphate- $\mathrm{PO}_{4}{ }^{3-}$ (molybdenum blue colorimetric method), ammonia- $\mathrm{NH}_{4}$ (nesslerisation colorimetric method), dissolved oxygen-DO (Wrinkler's titration), biochemical oxygen demand-BOD (dilution method with Winkler`s titration) and chemical oxygen demandCOD (potassium dichromate oxidation and titrimetry). Apparent colour developed during analysis was determined by measuring the absorbance at suitable wavelengths by using Cecil UV-Visible spectrophotometer (model CE 2501, 2000 series). Nickel, zinc, chromium, cobalt, copper, cadmium, calcium and lead were determined by atomic absorption spectrophotometry (Perkin Elmer model 2380). Quality control of metal measurements in the water was verified by including process blanks and carrying out recovery study. The mean percent of spiked samples were between $96.2 \%$ and $99.4 \%$. Standards for the atomic absorption analysis were obtained as the commercial BDH stock metal standards from which working standards were prepared by appropriate dilution. All the reagents utilized for sample preparation and analyses for all the parameters were obtained from Sigma Aldrich (London). Triplicate determination of each sample was carried out.

\section{Statistical analysis of analytical data}

The correlation between water quality upstream and downstream was assessed using the Kruskal-Wallis non-parametric Analysis of Variance on ranks (alpha $=0.050$ ). The differences observed between the levels of water quality at upstream and downstream locations were confirmed by Duncan multiple range test of variable at $p=0.05[16,17]$. All statistical analyses were performed using SPSS and Past software packages. Annual data for each parameter shown in Tables 1 and 2 are means of 72 and 180 values for upstream and downstream locations, respectively, i.e. three measurements of each parameter for 12 months for two (upstream) and five (downstream) sampling points, respectively.

\section{RESULTS AND DISCUSSION}

Water velocity and effluent flow rate

The ability of a river to transport pollutants in varying amounts depends on the water velocity, volume of water and steepness of the channel. The river flows in a laminar manner as the average water velocity is less than $1.5 \mathrm{~ms}^{-1}$ [18]. The average water velocity downstream was higher than what was obtained upstream. The average water velocities at upstream and downstream were $0.020 \pm 0.02 \mathrm{~ms}^{-1}$ and $0.41 \pm 0.01 \mathrm{~ms}^{-1}$, respectively (Table 2), while the effluent flowed with velocity of $0.32 \pm 0.01 \mathrm{~ms}^{-1}$ (Table 1 ).

pH, temperature and alkalinity

The average $\mathrm{pH}$ of the effluent was 5.2 \pm 0.7 within the range of 4.4-6.2 (Table 1). Most of $\mathrm{pH}$ values obtained on monthly basis were below the $\mathrm{pH}$ range 6.0-9.0 set as a standard by former 
Federal Environmental Protection Agency (FEPA), but now Federal Ministry of Environment in Nigeria and being proposed by India for effluent discharge into surface water. Certainly, the effluent is acidic and has the potential to acidify the Alaro river rendering it unwholesome for aquatic life. Aquatic biota are sensitive to extremes of $\mathrm{pH}$. The effluent may possibly contain weak acids such as $\mathrm{CO}_{2}$ and hydrated metal ions for instance $\mathrm{Al}\left(\mathrm{H}_{2} \mathrm{O}\right)_{6}{ }^{+}$, which contribute to the acidity. Acidity as applied to natural river water is not frequently encountered except in cases of severe pollution. The observed average $\mathrm{pH}$ of the effluent $(5.2 \pm 0.7)$ was much lower than $\mathrm{pH}$ 6.0 and 8.0 reported for effluents from Nasco and Cadbury Plc in Nigeria. Upon the receipt of the effluent by the Alaro river the water $\mathrm{pH}$ still increased by a unit. The average values of $6.9 \pm 0.2$ and $7.9 \pm 0.1$ were observed at upstream and downstream locations, respectively (Table 2).

Table 1. Quality of effluent discharged into the Alaro river compared with some food processing effluent qualities in Nigeria and other effluent quality standards.

\begin{tabular}{|c|c|c|c|c|c|c|c|c|}
\hline \multirow[t]{2}{*}{ Parameters } & \multicolumn{2}{|c|}{$\begin{array}{c}\text { Effluent discharge into } \\
\text { Alaro river }\end{array}$} & \multicolumn{2}{|c|}{$\begin{array}{c}\text { Some food processing } \\
\text { effluent qualities in } \\
\text { Nigeria }\end{array}$} & \multirow[b]{2}{*}{$\begin{array}{c}{ }^{\mathrm{b}} \mathrm{WHO} \\
\text { Discharge } \\
\text { limits }\end{array}$} & \multicolumn{3}{|c|}{ Effluent quality standards } \\
\hline & $\begin{array}{l}\text { *verall } \\
\text { average }\end{array}$ & Range & $\begin{array}{c}{ }^{\mathrm{a}} \mathrm{Nasco} \\
\text { (Biscuit } \\
\text { processing } \\
\text { plant) }\end{array}$ & $\begin{array}{c}{ }^{\mathrm{a}} \text { Cadbury } \\
\text { (Drinks } \\
\text { processin } \\
\text { g plant) }\end{array}$ & & $\begin{array}{c}{ }^{c} \text { European } \\
\text { Discharge } \\
\text { standards } \\
\text { (after Rijs, } \\
\text { 1994) }\end{array}$ & $\begin{array}{c}{ }^{\mathrm{d}} \text { Proposed } \\
\text { discharge } \\
\text { standards } \\
2006 \text { for } \\
\text { India }\end{array}$ & ${ }^{\mathrm{e}} \mathrm{FEPA}$ \\
\hline $\mathrm{pH}$ & $5.2 \pm 0.7$ & 4.4-6.2 & 6.0 & 8.0 & $6.5-9.5$ & - & $6.0-8.5$ & $6.0-9.0$ \\
\hline Temperature $\left({ }^{\circ} \mathrm{C}\right)$ & $27.2 \pm 5.4$ & $24-34$ & 29.0 & 30.6 & - & - & - & - \\
\hline $\mathrm{TS}(\mathrm{mg} / \mathrm{L})$ & $1860 \pm 340$ & $1250-2500$ & 300 & 2730 & - & - & - & - \\
\hline TDS (mg/L) & $1490 \pm 240$ & $118-2060$ & 210 & 2230 & 1000 & - & - & - \\
\hline TSS (mg/L) & $337 \pm 250$ & $87-1200$ & 90.0 & 500 & 30 & 30 & 20 & 30 \\
\hline Turbidity (FTU) & $25.4 \pm 10.2$ & $14-54$ & 13.2 & 15.0 & 5 & - & - & - \\
\hline $\begin{array}{l}\text { Total hardness } \\
(\mathrm{mg} / \mathrm{L})\end{array}$ & $1100 \pm 92$ & $870-1350$ & - & - & - & - & - & - \\
\hline Alkalinity $(\mathrm{mg} / \mathrm{L})$ & $599 \pm 160$ & $425-845$ & - & - & - & - & - & - \\
\hline $\mathrm{Cl}^{-}(\mathrm{mg} / \mathrm{L})$ & $566 \pm 100$ & $387-752$ & - & - & - & - & - & 600 \\
\hline $\mathrm{NO}_{3}{ }^{-}(\mathrm{mg} / \mathrm{L})$ & $47.3 \pm 6.8$ & $32.1-58.4$ & - & - & - & 15 & - & 20 \\
\hline $\mathrm{NH}_{3}(\mathrm{mg} / \mathrm{L})$ & $10.9 \pm 6.1$ & $4.25-15.2$ & - & - & - & - & 15 & - \\
\hline $\mathrm{SO}_{4}{ }^{2-}(\mathrm{mg} / \mathrm{L})$ & $44.2 \pm 9.8$ & $30.5-64.0$ & - & - & - & - & - & 500 \\
\hline $\mathrm{PO}_{4}{ }^{3-}(\mathrm{mg} / \mathrm{L})$ & $1.2 \pm 0.5$ & $0.52-1.85$ & - & - & - & 2 & 3 & 5 \\
\hline $\mathrm{DO}(\mathrm{mg} / \mathrm{L})$ & $0.67 \pm 0.34$ & $0-1.25$ & - & - & - & - & - & - \\
\hline $\mathrm{BOD}_{5}(\mathrm{mg} / \mathrm{L})$ & $13.2 \pm 2.7$ & $7.52-18.2$ & - & - & 50 & 20 & - & 50 \\
\hline COD (mg/L) & $865 \pm 350$ & $495-1840$ & - & - & 150 & 125 & 125 & - \\
\hline $\mathrm{Ca}(\mathrm{mg} / \mathrm{L})$ & $759 \pm 150$ & $520-925$ & - & - & - & - & - & 200 \\
\hline $\mathrm{Ni}(\mathrm{mg} / \mathrm{L})$ & $1.34 \pm 1.26$ & $0.17-3.1$ & - & - & - & - & 1.0 & $<1.0$ \\
\hline $\mathrm{Zn}(\mathrm{mg} / \mathrm{L})$ & $1.86 \pm 0.43$ & $1.45-2.52$ & - & - & - & - & 5.0 & 0.1 \\
\hline $\mathrm{Cr}(\mathrm{mg} / \mathrm{L})$ & $0.15 \pm 0.10$ & $0.03-0.27$ & - & - & - & - & 2 & $<1.0$ \\
\hline $\mathrm{Co}(\mathrm{mg} / \mathrm{L})$ & $0.38 \pm 0.27$ & $0.12-0.75$ & - & - & - & - & & - \\
\hline $\mathrm{Cu}(\mathrm{mg} / \mathrm{L})$ & $0.83 \pm 0.38$ & $0.52-1.57$ & - & - & - & - & 1.0 & $<1.0$ \\
\hline $\mathrm{Cd}(\mathrm{mg} / \mathrm{L})$ & $0.13 \pm 0.09$ & $0.03-0.24$ & - & - & - & - & & $<1.0$ \\
\hline $\mathrm{Pb}(\mathrm{mg} / \mathrm{L})$ & $1.64 \pm 0.67$ & $0.82-2.45$ & - & - & - & - & 0.1 & - \\
\hline Velocity $\left(\mathrm{ms}^{-1}\right)$ & $0.32 \pm 0.01$ & $0.26-0.35$ & - & - & - & - & - & - \\
\hline
\end{tabular}

${ }^{\mathrm{a}}$ Source $=[45] ;{ }^{\mathrm{b}}$ Source $=[46] ;{ }^{\mathrm{c}}$ Source $=$ Issued by the European Union and Dutch Government $[47] ;{ }^{\mathrm{d}}$ Source $=$ $[48]$; ${ }^{\text {Source }}=[49] .{ }^{*}$ Overall average $=$ Pooled mean \pm Pooled standard deviation. 
Table 2. Comparison of overall average water quality of the Alaro river with some water quality standards.

\begin{tabular}{|c|c|c|c|c|c|c|c|c|c|}
\hline \multirow[t]{2}{*}{ Parameters } & \multicolumn{4}{|c|}{ Alaro River } & \multicolumn{5}{|c|}{ Water Quality Standards } \\
\hline & Upstream & & Downstream & & ${ }^{\mathrm{f}} \mathrm{WHO}$ & ${ }^{g} \mathrm{CQC}$ & ${ }^{\mathrm{h}} \mathrm{FQC}$ & iUSEPA & jSON \\
\hline & Mean \pm SD & Range & Mean \pm SD & Range & & & & & \\
\hline $\mathrm{pH}$ & $6.9 \pm 0.2$ & $6.3-7.1$ & $6.9 \pm 0.1$ & $6.5-7.5$ & $6.5-9.5$ & $6.5-9.0$ & $6.5-8.0$ & $6.5-8.0$ & $6.5-8.5$ \\
\hline Temperature $\left({ }^{\circ} \mathrm{C}\right)$ & $26.4 \pm 0.1$ & $26.0-27.5$ & $27.0 \pm 0.2$ & $26.7-27.7$ & - & - & - & - & - \\
\hline TS (mg/L) & $250 \pm 4$ & $185-349$ & $1560 \pm 86$ & $1310-1930$ & - & - & - & - & - \\
\hline TDS $(\mathrm{mg} / \mathrm{L})$ & $178 \pm 3$ & $142-220$ & $1300 \pm 39$ & $1160-1280$ & $<1200$ & 500 & - & 500 & 500 \\
\hline TSS (mg/L) & $69.2 \pm 3.5$ & $42.4-125$ & $246 \pm 45$ & $150-669$ & - & - & - & - & - \\
\hline Turbidity (FTU) & $6.5 \pm 0.2$ & $2.0-12.5$ & $15.3 \pm 2.9$ & $8.1-20.2$ & 5 & - & - & - & - \\
\hline $\mathrm{Ca}^{2+}(\mathrm{mg} / \mathrm{L})$ & $113 \pm 6$ & $24.6-146$ & $216 \pm 64$ & $127-389$ & - & - & - & - & - \\
\hline $\begin{array}{l}\text { Total hardness } \\
(\mathrm{mg} / \mathrm{L})\end{array}$ & $132 \pm 5$ & $107-165$ & $268 \pm 71$ & $142-513$ & 500 & - & - & - & 150 \\
\hline Alkalinity $(\mathrm{mg} / \mathrm{L})$ & $83.1 \pm 1.5$ & $62.8-110$ & $158 \pm 49$ & $95.0-332$ & - & - & - & - & - \\
\hline $\mathrm{Cl}^{-}(\mathrm{mg} / \mathrm{L})$ & $157 \pm 4$ & $124-378$ & $307 \pm 27$ & $278-565$ & 250 & 250 & 200 & 250 & 250 \\
\hline $\mathrm{NO}_{3}^{-}(\mathrm{mg} / \mathrm{L})$ & $15.7 \pm 0.3$ & $11.1-146$ & $28.8 \pm 4.7$ & $24.0-35.8$ & 50.0 & - & $\begin{array}{l}10.0\left(\mathrm{NO}_{3}{ }^{-}\right. \\
\left.+\mathrm{NO}_{2}^{-}-\mathrm{N}\right)\end{array}$ & 10.0 & 50.0 \\
\hline $\mathrm{NH}_{3}(\mathrm{mg} / \mathrm{L})$ & $2.70 \pm 0.01$ & $1.61-4.32$ & $5.5 \pm 1.5$ & $5.04-9.6$ & $<1.5$ & - & 1.0 & - & - \\
\hline $\mathrm{SO}_{4}{ }^{2-}(\mathrm{mg} / \mathrm{L})$ & $9.65 \pm 0.39$ & \begin{tabular}{|l|}
$4.6-18.4$ \\
\end{tabular} & $18.9 \pm 4.3$ & $16.1-41.1$ & 500 & 500 & 250 & - & 100 \\
\hline $\mathrm{PO}_{4}{ }^{3-}(\mathrm{mg} / \mathrm{L})$ & $0.05 \pm 0.01$ & $0.02-0.15$ & $0.13 \pm 0.03$ & $0.05-0.46$ & - & - & 0.30 & - & - \\
\hline $\mathrm{DO}(\mathrm{mg} / \mathrm{L})$ & $5.42 \pm 0.03$ & $2.08-6.2$ & $4.1 \pm 1.1$ & $0.86-4.4$ & - & $5.5-9.5$ & $\geq 5.0$ & - & - \\
\hline $\mathrm{BOD}(\mathrm{mg} / \mathrm{L})$ & $2.12 \pm 0.01$ & $1.83-3.17$ & $7.3 \pm 1.2$ & $5.4-8.75$ & - & - & $\leq 6.0$ & - & - \\
\hline $\mathrm{COD}(\mathrm{mg} / \mathrm{L})$ & $103 \pm 5$ & \begin{tabular}{|l|}
$48.0-196$ \\
\end{tabular} & $500 \pm 39$ & $324-1010$ & - & - & - & - & - \\
\hline $\mathrm{Ni}(\mathrm{mg} / \mathrm{L})$ & $0.54 \pm 0.02$ & $0.07-1.02$ & $0.88 \pm 0.13$ & $0.12-1.79$ & 0.02 & 0.025 & 0.03 & 0.05 & 0.02 \\
\hline $\mathrm{Zn}(\mathrm{mg} / \mathrm{L})$ & $0.59 \pm 0.02$ & $0.31-0.70$ & $0.65 \pm 0.21$ & $0.34-0.78$ & 0.01 & 0.03 & 0.20 & 0.12 & 3.0 \\
\hline $\mathrm{Cr}(\mathrm{mg} / \mathrm{L})$ & $0.25 \pm 0.02$ & \begin{tabular}{|l|}
$0.07-0.26$ \\
\end{tabular} & $0.06 \pm 0.02$ & $0.09-0.85$ & - & 0.05 & 0.05 & 0.10 & - \\
\hline Co $(\mathrm{mg} / \mathrm{L})$ & $0.27 \pm 0.06$ & $0.04-0.27$ & $0.26 \pm 0.02$ & $0.06-0.34$ & - & 0.05 & - & - & - \\
\hline $\mathrm{Cu}(\mathrm{mg} / \mathrm{L})$ & $0.04 \pm 0.01$ & \begin{tabular}{|l|}
$0.15-0.27$ \\
\end{tabular} & $0.04 \pm 0.01$ & $0.26-0.45$ & - & 0.024 & 0.05 & 0.009 & 1.0 \\
\hline $\mathrm{Cd}(\mathrm{mg} / \mathrm{L})$ & $0.04 \pm 0.01$ & \begin{tabular}{|l|}
$0.02-0.04$ \\
\end{tabular} & $0.04 \pm 0.01$ & $0.03-0.07$ & 0.003 & - & 0.001 & 0.002 & 0.003 \\
\hline $\mathrm{Pb}(\mathrm{mg} / \mathrm{L})$ & $0.17 \pm 0.02$ & \begin{tabular}{|l|}
$0.05-0.21$ \\
\end{tabular} & $0.32 \pm 0.10$ & $0.15-0.60$ & 0.01 & 0.017 & 0.05 & 0.003 & 0.01 \\
\hline Velocity $\left(\mathrm{ms}^{-1}\right)$ & $0.20 \pm 0.02$ & $0.18-0.22$ & $0.41 \pm 0.01$ & $0.39-0.43$ & - & - & - & - & - \\
\hline
\end{tabular}

$\mathrm{WHO}=\mathrm{WHO}$ drinking water guidelines, $\mathrm{CQC}=$ Canadian water quality criteria for aquatic freshwater life, $\mathrm{FQC}$ $=$ Flemish quality criteria for aquatic freshwater. USEPA = US Environmental Protection Agency. SON= Standard Organization of Nigeria. ${ }^{\mathrm{f}}$ Source $=[28] ;{ }^{\mathrm{g}}$ Source $=[50] ;{ }^{\mathrm{h}}$ Source $=[51] ;{ }^{\mathrm{i}}$ Source $=[52] ;{ }^{\mathrm{j}}$ Source $=[53]$.

The temperature of the effluent was $27.2 \pm 5.4{ }^{\circ} \mathrm{C}$ ranging from 24 to $34{ }^{\circ} \mathrm{C}$. An increase in water temperature by any degree, being an important factor controlling the solubility of oxygen in the river required to sustain aquatic life, would not slow down the chemical and biological processes occurring in the river [19]. The alkalinity levels of the effluent ranged from $425 \mathrm{mg} / \mathrm{L}$ to $845 \mathrm{mg} / \mathrm{L}$ with an average level of $599 \pm 160 \mathrm{mg} / \mathrm{L}$ (Table 1). The portion of dissolved solids of the effluents containing carbonates, bicarbonates, sulfates, and chlorides of magnesium and calcium could have contributed to alkalinity level of the water downstream as the effluent disperses in the river. Other major factor that could possibly be responsible for the increase in alkalinity is the weathering of carbonate minerals downstream, which process requires the presence and participation of both water and carbondioxide. An increase in aquatic plant and microbial production of carbondioxide can enhance the weathering process and consequently elevate the alkalinity level [20, 21]. Alkalinity neutralizes acidity and complexes dissolved metal. A river with high alkalinity levels will be able to supply adequate amounts of carbonate, bicarbonate and hydroxide ions in solution to bind up free protons and metals. Therefore, an increase in alkalinity levels downstream reduces water acidity of the Alaro river as reflected in measures of water $\mathrm{pH}(7.9 \pm 0.1)$ downstream (Table 2$)$. A river with high $\mathrm{pH}$ generally contains elevated levels of dissolved solids. Besides, it appeared that as solids substances that looked like salts settled out, it carried suspended matter with it. There was a strong positive correlation 
between the alkalinity level downstream and suspended solids levels $(r=0.952)$. Similarly, the alkalinity level correlated strongly $(r=0.939)$ with the dissolved solids of the downstream (Table 3).

\section{Total solids, suspended solids and dissolved solids}

The total solids (TS) of the effluent ranged from $1250 \mathrm{mg} / \mathrm{L}$ to $2500 \mathrm{mg} / \mathrm{L}$. The effluent had high total suspended solids (TSS) with an average level of $337 \pm 250 \mathrm{mg} / \mathrm{L}$ ranging from $87 \mathrm{mg} / \mathrm{L}$ to $1200 \mathrm{mg} / \mathrm{L}$. The range of TSS shows that the level of suspended solids are higher than 30 $\mathrm{mg} / \mathrm{L}$ set as European discharge limit for TSS (Table 1). Effluents from food and beverages industries are characterised with suspended materials such as coagulated milk, particles of cheese curd and concentrates. The inflow of the effluent resulted to an increase in TS, total dissolved solids (TDS) and TSS level downstream. The average TDS levels downstream were much higher than the limit of $1200 \mathrm{mg} / \mathrm{L}$ given by WHO (Table 2). The cloudiness or nontransparency of the river is traceable to the high dissolved solids level downstream, $1300 \pm 39$ $\mathrm{mg} / \mathrm{L}$ (Table 2). High level of solids generally together with non-transparency of the river water can impair photosynthetic process, which is particularly important for aquatic plants. The offensive odour that evolves occasionally from the river is traceable to the decomposition of sludge beds formed. Sludge bed is referred to as the bottom deposit of organic matter that binds with suspended solids in the river. In addition to the adverse aesthetic ecological effects of high suspended solids level, it can interfere with purification cost of the water if it were to be treated for pipe borne water supply to the public. It is noteworthy that the nature of suspended solids in the river and effluent's composition are important factors in the designing of a suitable treatment method for effluents and river water [22].

The impact of pollution from untreated discharges lingers to a farther point downstream where water from effluent-receiving river is relied upon for drinking, irrigation and recreational purposes [23]. The use of untreated river water as an alternative for drinking water arises not only from acute water shortage but also due to poor management of river water [24]. Reasoning from the dependence of the populace on untreated water for drinking purpose, detailed quality parameters of the Alaro river downstream were compared with drinking water standards and water quality characteristics in relation to various beneficial purposes (Table 3). The average TDS levels downstream were much higher than the limit of $1200 \mathrm{mg} / \mathrm{L}$ given by WHO and Standard Organisation of Nigeria-SON (Table 2). The use of the Alaro river for irrigation system is out of order as far as annual TDS levels which are far above the allowable limit of 500 $\mathrm{mg} / \mathrm{L}$ are concerned (Table 3 ).

\section{Calcium, total hardness and turbidity}

Calcium contents of the river and total hardness level at downstream were much higher than the corresponding level at upstream. The river experienced an increase in calcium contents with the inflow of the effluent whose calcium level increased with the sampling periods. The discharge of the effluent with total hardness of $1100 \pm 92 \mathrm{mg} / \mathrm{L}$ into the river accounted for the increase in hardness levels downstream. The increase in hardness and calcium levels downstream was observed all through the sampling periods. This implies that the river presumably has been accumulating much dissolved calcium and magnesium ions that could possibly cause hardness. An increase in hardness level adversely affects detergent performance which constitutes the major problem to people who rely on the water downstream for laundry purpose. Some food vendors whose kiosks are closed to the Alaro river and who fetch it's water for food processing will possibly be observing white precipitate of $\mathrm{CaCO}_{3}$ on the cooking pots. The maximum permissible limit of $500 \mathrm{mg} / \mathrm{L}$ is required by WHO for water above which it is described as hard 
water. Water of hardness level $50-100 \mathrm{mg} / \mathrm{L}$ is classified as moderately soft, while $100-150$ $\mathrm{mg} / \mathrm{L}$ is slightly hard $[23,25]$.

Table 2 reveals lower turbidity levels at upstream location than levels at downstream location, suggesting that the Alaro river is more transparent at upstream than at downstream location. Overall turbidity level of $15.3 \pm 2.9 \mathrm{FTU}$ at downstream location was much higher than 5 FTU indicated by WHO for drinking water and domestic water supply (Tables 2 and 3). Turbidity of the river for these sampling periods have positive correlation values $(r=0.833)$ with suspended solids, which equally increased in level downstream (Table 4).

Table 3. Comparison of average water quality of the Alaro river with optimum values of water quality characteristics in relation to type of beneficial use.

\begin{tabular}{|c|c|c|c|c|c|c|c|}
\hline \multirow[t]{2}{*}{ Parameters } & \multicolumn{2}{|c|}{ Alaro river } & \multirow{2}{*}{\begin{tabular}{|c|}
$\begin{array}{c}{ }^{\mathrm{D}} \text { Domestic } \\
\text { water } \\
\text { supply }\end{array}$ \\
\end{tabular}} & \multirow{2}{*}{$\begin{array}{l}{ }^{\mathrm{k}} \text { Recreation } \\
\text { (bathing and } \\
\text { swimming) }\end{array}$} & \multirow{2}{*}{$\begin{array}{c}{ }^{\mathrm{k}} \text { Wildlife } \\
\text { propagation } \\
\text { (fish) }\end{array}$} & \multirow[t]{2}{*}{${ }^{\mathrm{k}}$ Irrigation } & \multirow{2}{*}{$\begin{array}{c}{ }^{\mathrm{k}} \text { Industrial } \\
\text { (food } \\
\text { processing) }\end{array}$} \\
\hline & Upstream & Downstream & & & & & \\
\hline $\mathrm{pH}$ & $6.9 \pm 0.2$ & $6.9 \pm 0.1$ & $6.8-7.2$ & $6.8-7.2$ & $6.5-8.5$ & $6.5-8.5$ & $6.5-8.5$ \\
\hline Temperature $\left({ }^{\circ} \mathrm{C}\right)$ & $26.4 \pm 0.1$ & $27.0 \pm 0.2$ & - & - & - & - & - \\
\hline TS (mg/L) & $250 \pm 4$ & $1560 \pm 86$ & 500 & - & 1000 & 500 & 500 \\
\hline TDS (mg/L) & $178 \pm 3$ & $1300 \pm 39$ & - & - & - & 500 & - \\
\hline TSS (mg/L) & $69.2 \pm 3.5$ & $246 \pm 45$ & - & 100 & - & - & - \\
\hline Turbidity (FTU) & $6.5 \pm 0.2$ & $15.3 \pm 2.9$ & 5.0 & 5.0 & 5.0 & - & 5.0 \\
\hline $\mathrm{Ca}^{2+}(\mathrm{mg} / \mathrm{L})$ & $113 \pm 6$ & $216 \pm 64$ & - & - & - & - & - \\
\hline $\begin{array}{l}\text { Total hardness } \\
(\mathrm{mg} / \mathrm{L})\end{array}$ & $132 \pm 5$ & $268 \pm 71$ & 100 & - & - & - & - \\
\hline Alkalinity (mg/L) & $83.1 \pm 1.5$ & $158 \pm 49$ & - & - & - & - & - \\
\hline $\mathrm{Cl}^{-}(\mathrm{mg} / \mathrm{L})$ & $157 \pm 4$ & $307 \pm 27$ & 750 & - & 2500 & 750 & 1000 \\
\hline $\mathrm{NO}_{3}^{-}(\mathrm{mg} / \mathrm{L})$ & $15.7 \pm 0.3$ & $28.8 \pm 4.7$ & - & - & - & - & - \\
\hline $\mathrm{NH}_{3}(\mathrm{mg} / \mathrm{L})$ & $2.70 \pm 0.01$ & $5.5 \pm 1.5$ & - & - & - & - & - \\
\hline $\mathrm{SO}_{4}{ }^{2-}(\mathrm{mg} / \mathrm{L})$ & $9.65 \pm 0.39$ & $18.9 \pm 4.3$ & - & - & - & - & - \\
\hline $\mathrm{PO}_{4}{ }^{3-}(\mathrm{mg} / \mathrm{L})$ & $0.05 \pm 0.01$ & $0.13 \pm 0.03$ & - & - & - & - & - \\
\hline $\mathrm{DO}(\mathrm{mg} / \mathrm{L})$ & $5.42 \pm 0.03$ & $4.1 \pm 1.1$ & 5.0 & 5.0 & 5.0 & - & 5.0 \\
\hline $\mathrm{BOD}(\mathrm{mg} / \mathrm{L})$ & $2.12 \pm 0.01$ & $6.3 \pm 1.2$ & - & 5.0 & 10.0 & - & - \\
\hline $\mathrm{COD}(\mathrm{mg} / \mathrm{L})$ & $103 \pm 5$ & $500 \pm 39$ & - & - & - & - & - \\
\hline
\end{tabular}

${ }^{\mathrm{k}}$ Source $=[54]$.

Anions

The average chloride level in the effluent was $566 \pm 100 \mathrm{mg} / \mathrm{L}$ with a range of $387-752 \mathrm{mg} / \mathrm{L}$. The range revealed that chloride levels observed during some sampling periods were much higher than the permissible chloride limit of $600 \mathrm{mg} / \mathrm{L}$ for effluent discharge into surface water in Nigeria (Table 1). The discharge of effluent into the Alaro river constituted a pollution source of chloride in addition to the chloride level sourced from the dissolved mineral in the river. The average chloride content of $307 \pm 27 \mathrm{mg} / \mathrm{L}$ was above the acceptable chloride limit of $250 \mathrm{mg} / \mathrm{L}$ set by USEPA for aquatic life and water quality for drinking water (Table 2). It has been reported in the literature of rivers Upper Volga and Danube which have elevated levels of chloride downstream with a corresponding low chloride level upstream upon the receipt effluent $[26,27]$.

The level of nitrate in the effluent varied between $32.1 \mathrm{mg} / \mathrm{L}$ and $58.4 \mathrm{mg} / \mathrm{L}$. These levels are much higher than $20 \mathrm{mg} / \mathrm{L}$ of nitrate, which is the allowable limit for effluent discharge into 
river. The level of nitrate was raised at downstream above the background level upstream. The average nitrate levels downstream ranged from $24.0 \mathrm{mg} / \mathrm{L}$ to $35.8 \mathrm{mg} / \mathrm{L}$ (Table 2). Overall nitrate level of $28.8 \pm 4.7 \mathrm{mg} / \mathrm{L}$ at downstream location was much higher than allowable limit of $10 \mathrm{mg} / \mathrm{L}$ for supporting aquatic freshwater life and USEPA limit (Table 2). Excessive levels of nitrates are associated with methaemoglobinaemia in bottle-fed infants when contaminated water is the source of drinking water [28]. Methaemoglobinaemia in infants has been reported in a number of countries, particularly in Eastern Europe [29]. The processes leading to nitrate formation from organic load of the effluent are mostly bacterial transformations. The oxidation of ammonium in the organic load to nitrate by nitrifying bacteria probably present in the river water is termed nitrification.

The discharge of effluent into the Alaro river resulted to overall ammonia level of $5.5 \pm 1.5$ $\mathrm{mg} / \mathrm{L}$ at downstream. This was much higher than the permissible ammonia limit of $1.0 \mathrm{mg} / \mathrm{L}$ for freshwater and WHO limit of $1.5 \mathrm{mg} / \mathrm{L}$ (Table 2). High level of ammonia in the river is traceable to the use of ammonium bicarbonate as one of the raw materials for biscuits production in the company whose effluent flows into the Alaro river. Ammonia bicarbonate aids dough rising and its dissolution in river water possibly evolves ammonia. Also, the effluent from the food manufacturing may possibly contain traces of glutathione. The anaerobic decay of protein bound glutathione substance in the effluent to release ammonia as a form of nitrogen is a possibility. Glutathione has been recognized as a naturally occurring compound in wheat flour and it plays an important role in redox reactions in baking technology [30]. The anaerobic decomposition process in which protein containing materials and other organic matter are broken down by bacteria using nitrate as an electron acceptor is called denitrification. The denitrification process occurs in two steps. The first step is the reduction of nitrate to nitrous oxide which can further be reduced to nitrogen. Both nitrous and nitrogen can be emitted into the atmosphere. Nitrous oxide is a greenhouse gas and its excessive emission may contribute to the global warming problem. At low $\mathrm{pH}$, the second step of dentrification can be inhibited, so that all nitrogen will be released in the form of nitrous oxide [31]. From an environmental quality perspective, the $\mathrm{pH}$ above 6.0 as obtained for the Alaro river in this study will encourage denitrification of a large proportion of nitrate which can evolve as atmospheric nitrogen.

The average level of phosphate in the effluent was $1.2 \pm 0.5 \mathrm{mg} / \mathrm{L}$. The release of detergents used for washing in the factories is a probable source of phosphate in the Alaro river. Although the phosphate level at the discharge point is below the nationally recommended maximum limit of $5.0 \mathrm{mg} / \mathrm{L}$ set by FEPA, it is nevertheless not too low as to encourage the proliferation of algae growth. The phosphate level was observed to be low generally at upstream locations where anthropogenic pollution was minimal. This is in agreement with the findings which reveal that inflow streams are low in phosphate when they are not influenced by human activities [32]. It was reported that phosphate concentration greater than $0.1 \mathrm{mg} / \mathrm{L}$ is regarded as unacceptably high in most freshwater system [33]. It has been pointed out that if phosphate phosphorus is present in water, a concentration of $0.30 \mathrm{mg} / \mathrm{L}$ of nitrate coupled with the available phosphate is enough to cause an increase in algae growth [34]. Since the average nitrate level in the Alaro river was above $0.30 \mathrm{mg} / \mathrm{L}$, eutrophication process in the river would be expected to accelerate dissolved oxygen depletion.

\section{Measures of organic pollution (DO, BOD and COD)}

Dissolved oxygen (DO) level in the effluent ranged from 0 to $1.25 \mathrm{mg} / \mathrm{L}$ (Table 1). The dissolved oxygen range is far below the recommended minimum of $5.0 \mathrm{mg} / \mathrm{L}$ for aquatic life and could encourage septic condition in the river (Table 2). This condition is detrimental to aquatic life. The overall downstream DO level of $4.1 \pm 1.1 \mathrm{mg} / \mathrm{L}$ was much lower than the corresponding upstream DO levels of $5.42 \pm 0.30 \mathrm{mg} / \mathrm{L}$. These dissolved oxygen levels were 
observed to be lower than the permissible DO limit $(5.5-9.5 \mathrm{mg} / \mathrm{L})$ for aquatic freshwater life despite the dilution of effluent that could have occurred as the river flowed downstream (Table 2). One major pollutant in the effluents from food and beverage industries is organic material which is decomposable by micro-organisms in the river. But in breaking down the organic pollutant, the micro-organism consumes the available oxygen in the water. The susceptibility of aquatic life to toxic substance in the effluent is expected to increase when the level of dissolved oxygen is depleted.

The $\mathrm{BOD}_{5}$ and COD levels of the effluent were $13.2 \pm 2.7 \mathrm{mg} / \mathrm{L}$ and $866 \pm 350 \mathrm{mg} / \mathrm{L}$, respectively (Table 1). The level of BOD of the effluent in this study is far below the BOD level of $1318 \mathrm{mg} / \mathrm{L}$ reported for a similar food manufacturing and beverage industries in Ghana [35]. The overall $\mathrm{BOD}_{5}(2.12 \pm 0.01 \mathrm{mg} / \mathrm{L})$ and COD $(103 \pm 5 \mathrm{mg} / \mathrm{L})$ levels of upstream increased to $7.3 \pm 1.2 \mathrm{mg} / \mathrm{L}$ and $500 \pm 39 \mathrm{mg} / \mathrm{L}$, respectively, at downstream location. This increase was due to the inflow effluent with high decomposable organic matter present in wastewaters resulting from the rinsing of bottles, baking tray and mixing tanks. The overall BOD levels of $7.3 \pm 1.2$ $\mathrm{mg} / \mathrm{L}$ exceeded the quality standard of $6.0 \mathrm{mg} / \mathrm{L}$ required for aquatic freshwater (Table 2 ). The principal industrial contributor of BOD loading of most rivers is the food manufacturing sector [1]. The problem associated with river having high $\mathrm{BOD}_{5}$ ranges from high bacterial population to very low oxygen level $[31,36]$.

\section{Metals}

High levels of $\mathrm{Ni}, \mathrm{Zn}, \mathrm{Cr}, \mathrm{Co}, \mathrm{Cu}, \mathrm{Cd}$ and $\mathrm{Pb}$ in downstream water were primarily the result of pollution resulting from effluent discharges in the river. The overall levels of these metals were much higher than their corresponding levels upstream, WHO and other quality standards for aquatic freshwater life. Table 1 reveals the following overall dissolved metal concentrations of $0.88 \pm 0.12 \mathrm{mg} / \mathrm{L}, 0.65 \pm 0.21 \mathrm{mg} / \mathrm{L}, 0.06 \pm 0.02 \mathrm{mg} / \mathrm{L}, 0.26 \pm 0.02 \mathrm{mg} / \mathrm{L}, 0.04 \pm 0.01 \mathrm{mg} / \mathrm{L}$ and $0.32 \pm$ $0.10 \mathrm{mg} / \mathrm{L}$ downstream for $\mathrm{Ni}, \mathrm{Zn}, \mathrm{Cr}, \mathrm{Co}, \mathrm{Cu}, \mathrm{Cd}$ and $\mathrm{Pb}$, respectively. In many countries, industrial wastewater is often mixed with municipal wastewater and is used for irrigation. Industrial wastes may contain toxic organic and inorganic chemicals that can be taken up by crops. For example, in Japan, China including the province of Taiwan, rice accumulated high concentrations of cadmium (and other heavy metals) when it was grown in soils contaminated with irrigation water containing high levels of industrial discharges [37]. In Japan, Itai-Itai disease - a bone and kidney disorder - associated with chronic cadmium poisoning, occurred in areas where rice paddies were irrigated with water from the contaminated Jinzu river [38]. In some ingested parts of China, the use of industrial wastewater for irrigation is thought to be associated with health effects. For example, in affected areas a 36\% increase in hepatomegaly (enlarged liver), and a $100 \%$ increase in both cancer and congenital malformation rates were observed compared to control areas where industrial wastewater was not used for irrigation [39]. Since water from the Alaro river is a common source of irrigation for many vegetables along the blank of river, accumulation of heavy metals by crops irrigated with industrial wastewater is a possibility. Some metals such as $\mathrm{Zn}$, $\mathrm{Co}$ and $\mathrm{Cu}$ are essential micro-nutrients and have a variety of biochemical functions in all living organisms and crops. While the elements are essential, they can be toxic when in excess [40, 41]. Some metals like lead and cadmium are non-essential metals as they are toxic, even in traces [42, 43]. As such, consumption of such vegetables could induce heavy metal hazards in humans. Chromium is a known lung carcinogen and it is toxic through oral or dermal exposure [44]. 
Pollution effect of food and beverages effluents on the Alaro river in Ibadan city, Nigeria 357

Table 4. Correlation coefficients (r) for the pairs of water quality characteristics of Alaro river.

\begin{tabular}{|c|c|c|c|c|c|c|c|c|c|c|c|c|c|c|c|}
\hline & & & & & & & & & $\mathrm{Pb}$ & $\mathrm{Ni}$ & $\mathrm{Cu}$ & $\mathrm{Cr}$ & $\mathrm{Co}$ & $\mathrm{Cd}$ & \\
\hline $\mathrm{TS}$ & -0.53 & & & & & & & & 0.86 & 0.85 & 0.87 & 0.87 & -0.07 & 0.88 & $\mathrm{Zn}$ \\
\hline TDS & -0.25 & 0.94 & & & & & & & & 0.92 & 0.97 & 0.93 & -0.13 & 0.89 & $\mathrm{~Pb}$ \\
\hline TSS & -0.50 & 0.99 & 0.95 & & & & & & & & 0.98 & 0.87 & -0.18 & 0.83 & $\mathrm{Ni}$ \\
\hline Turbidity & -0.35 & 0.89 & 0.88 & 0.83 & & & & & & & & 0.88 & -0.11 & 0.87 & $\mathrm{Cu}$ \\
\hline Alkalinity & -0.31 & 0.93 & 0.94 & 0.95 & 0.95 & & & & & & & & -0.16 & 0.79 & $\mathrm{Cr}$ \\
\hline $\begin{array}{l}\text { Total } \\
\text { hardness }\end{array}$ & -0.23 & 0.89 & 0.89 & 0.89 & 0.95 & 0.99 & & & & & & & & 0.38 & $\mathrm{Co}$ \\
\hline $\mathrm{Cl}^{-}$ & -0.27 & 0.61 & 0.61 & 0.65 & 0.74 & 0.80 & 0.87 & & & & & & & & \\
\hline $\mathrm{NO}_{3}{ }^{-}$ & -0.42 & 0.98 & 0.95 & 0.99 & 0.94 & 0.97 & 0.92 & 0.67 & & & & & & & \\
\hline $\mathrm{NH}_{3}$ & -0.35 & 0.92 & 0.92 & 0.95 & 0.98 & 0.99 & 0.98 & 0.81 & 0.967 & & & & & & \\
\hline $\mathrm{SO}_{4}{ }^{2-}$ & -0.31 & 0.86 & 0.83 & 0.95 & 0.97 & 0.97 & 0.97 & 0.82 & 0.93 & 0.98 & & & & & \\
\hline $\mathrm{PO}_{4}{ }^{3-}$ & 0.18 & 0.55 & 0.71 & 0.62 & 0.83 & 0.80 & 0.86 & 0.73 & 0.68 & 0.81 & 0.83 & & & & \\
\hline DO & -0.24 & -0.94 & \begin{tabular}{|l|}
-0.98 \\
\end{tabular} & -0.96 & \begin{tabular}{|l|}
-0.93 \\
\end{tabular} & -98 & -0.95 & \begin{tabular}{|l|}
-0.68 \\
\end{tabular} & \begin{tabular}{|l|}
-0.98 \\
\end{tabular} & \begin{tabular}{|l|}
-0.96 \\
\end{tabular} & \begin{tabular}{|l|}
-0.92 \\
\end{tabular} & -0.92 & & & \\
\hline BOD & -0.60 & 0.90 & 0.99 & 0.98 & 0.85 & 0.89 & 0.81 & 0.57 & 0.96 & 0.89 & 0.83 & 0.47 & -0.90 & & \\
\hline COD & -0.42 & 0.98 & 0.92 & 0.97 & 0.88 & 0.94 & \begin{tabular}{|l|}
0.88 \\
\end{tabular} & 0.61 & 0.99 & 0.92 & 0.90 & 0.59 & -0.96 & 0.97 & \\
\hline & $\mathrm{pH}$ & TS & TDS & TSS & Turbidity & Alkalinity & $\begin{array}{c}\text { Total } \\
\text { hardness }\end{array}$ & $\mathrm{Cl}^{-}$ & $\mathrm{NO}_{3}{ }^{-}$ & $\mathrm{NH}_{3}$ & $\mathrm{SO}_{4}{ }^{2-}$ & $\mathrm{PO}_{4}{ }^{3-}$ & DO & BOD & \\
\hline
\end{tabular}

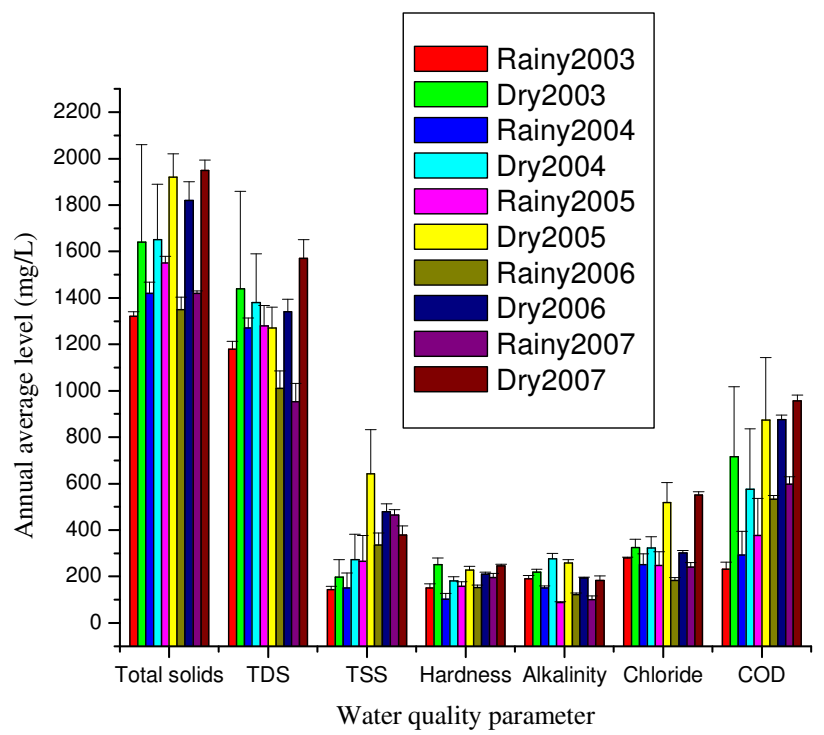

Figure 2. Temporal and seasonal variations of total solids (TS), total dissolved solids (TDS), total suspended solids (TSS), total hardness, alkalinity, chloride and COD levels downstream location between sampling period 2003 and 2007. 


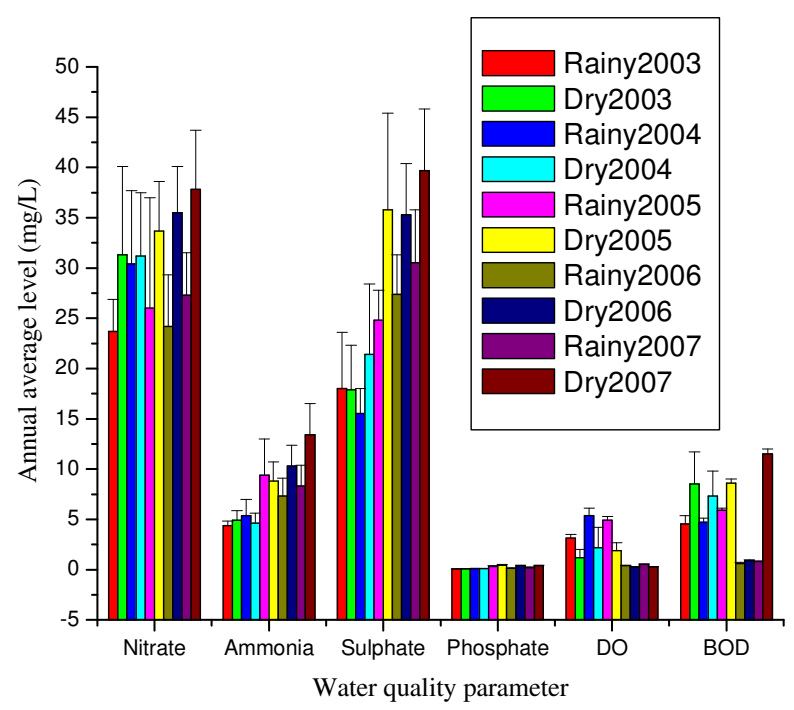

Figure 3. Temporal and seasonal variations of nitrate, ammonia, sulfate, phosphate, DO and BOD levels downstream location between sampling period 2003 and 2007.

Spatial and seasonal trends in water quality at discharge and downstream locations

Figures 2 and 3 show the pattern of spatial and seasonal variability of water quality parameters of the Alaro river downstream between 2003 and 2005. These parameters include TS, TDS, TSS, total hardness, $\mathrm{SO}_{4}{ }^{2-}, \mathrm{PO}_{4}{ }^{3-}, \mathrm{NO}_{3}{ }^{-}, \mathrm{NH}_{3}, \mathrm{Cl}^{-}$, alkalinity, $\mathrm{BOD}, \mathrm{COD}$ and DO whose levels in dry season were different from the corresponding levels in dry season. This suggests that the Alaro river is subject to climatic variation. In terms of composition, the levels of water quality parameters were much lower in the rainy season than the dry season. This implies that that there was improvement in the river quality in the rainy season compared with the dry season owing to (i) much dilution from the upstream and (ii) the reduced input of effluent discharges during the dry season. During the dry season, the health of the river's aquatic ecosystem may be significantly jeopardized. BOD, COD and DO distribution patterns reveal more contribution of organic load at downstream location during the dry season than the rainy season.

\section{CONCLUSIONS}

Effluents from food and beverages industries in Ibadan city contributed significant pollution load to the Alaro river. The river is a recipient of effluents of poor quality. Some identified pollutants in the combined effluent are organic load, suspended solids, phosphate, nitrate and chloride which led to significant pollution of the Alaro river water. The receipt of the combined effluent has rendered the river unwholesome for certain beneficial purposes such as cooking, drinking, irrigation and aquatic life support. Thus the effluent has a profound impact on the physicochemical structure of the Alaro river and also affects the consumers of the river water. It is suggested that discharges from these industries should be given very high degree of treatment before final exist to the Alaro river. 
Pollution effect of food and beverages effluents on the Alaro river in Ibadan city, Nigeria 359

\section{REFERENCES}

1. Scheren, P.A.; Ibe, A.C.; Janssen, F.J.; Lemmens, A.M. Marine Pollut. Bull. 2002, 44, 633.

2. Kirby, R.M.; Bartram, J.; Carr, R. Food Control 2003, 14, 283.

3. Kondro, W. Lancet 2000, 355, 2058.

4. Kramer, M.H.; Herwaldt, B.L.; Calderon, R.L.; Juranek, D.D. CDC Surveillance Summaries MMWR Weekly Report, 1996, 45(SS-1), p 1.

5. Hoxie, N.J.; Davis, J.P.; Vergeront, J.M.; Nashold, R.D.; Blair, K.A. Am. J. Public Health 1997, 87, 2032.

6. Shuval, H.I. Technical Paper, World Bank: Washington, DC; 1986, 51, p 1

7. Sridhar, M.K.C.; Oluwande, P.A.; Okubadejo, A.O. Ambio. 1981, 10, 29.

8. Adesina, H.O. Proceedings of National Conference on Development and the Environment, Institute of Social and Economic Research, Ibadan, Nigeria; 1986; p 234.

9. Rosenblum, L.S.; Mirkin, I.R.; Allen, D.T.; Safford, S.; Hadler, S.C. Am. J. Public Health 1990, 80, 1075.

10. Williams, I.T.; Bell, B.; Berry, D.; Shapiro, C. Epidemic Intelligence Service, 44th Annual Conference, March 27-31, Centers for Disease Control and Prevention: Atlanta, Georgia; 1994; $\mathrm{p} 19$.

11. Ramsay, C.N.; Upton, P.A. Lancet 1989, 1, 43.

12. Shiklomanov, I.A. Report for the Comprehensive Assessment of the Freshwater Resources of the World, United Nations: New York; 1998; p 1

13. ASTM Annual Book of ASTM Standards, Part 31, Washington, DC; 1982; p 1

14. APHA-AWWA-WPCF Standard Methods for the Examination of Water and Wastewater 20th ed., APHA-AWWA-WPCF: Washington, DC; 1998; $\mathrm{p} 1$

15. Georgi, G. J. Hydrology 1971, 14, 293.

16. Kruskal, W.H.; Wallis, A. J. Am. Statistics Assoc. 1952, 47, 588.

17. Ducan, D.B. Biometrics 1955, 11, 1.

18. Raymond, S. Earth, 4th ed., Frank Press: New York; 1986; p 1

19. McDonald, L.H.; Smart, A.W.; Wissmar, R.C. EPA 910/9-91-001-CSS/EPA, USEPA: Seattle, USA; 1991; $p 1$

$\begin{array}{lllll}\text { 20. Sherwood, } \quad \text { K.; } & \text { Craig, } & \text { I. } & \mathrm{CO}_{2} & \text { Science, 2003, 6(52). }\end{array}$ http://www.CO2science.org/articles/V6/N52/EDIT.Php, Accessed on 20th September 2010.

21. Raymond, P.A.; Cole, J.J. Science 2003, 301, 33.

22. Zhou, Z.; Bateman, J.C.; Babchin, A.; Bird, G.W. J. Environ. Quality 1994, 23, 746.

23. Ipeaiyeda, A.R.; Onianwa, P.C. Chemistry and Ecology 2009, 25, 189.

24. World Water Council, World Water Vision Commission Report in Making Water Everybody's Business, Cosgrove, W.R.; Rijsberman, F.R. (Eds.), http://www.earthscan.co.uk, Accessed on 18th February 2010.

25. Onianwa, P.C.; Ogunniyi, O.J.; Ogunlowo, A.A. Intern. J. Environ. Educ. Inform. 1999, 18, 143.

26. Chernyavskaya, A.P.; Denisava, A.I.; Babich, I.I.; Zima, S.A.; Gerashchenko, L.V.; Serebryakova, T.M.; Isseranich, V.V.; Krut'Ko, O.F. Water Resour. 1993, $20,440$.

27. River, I.K., Litvinov, A.A. Water Resour. 1997, 24, 546.

28. World Health Organization (WHO) Guideline for Drinking Water Quality Recommendations 2, World Health Organization: Geneva; 1996; 1.

29. Knobeloch, L.; Salna, B.; Hogan, A.; Postle, J.; Anderson, H. Environ. Health Perspect. 2000, 108, 675.

30. Li, W.; Bollecker, S.S.; Schofield, J.D. J. Cereal Sci. 2004, 39, 205.

31. Verhoeven, J.T.A.; Meuleman, A.F.M. Ecological Engineering 1999, 12, 5.

32. Rast, I.N.; Holland, M. Ambio. 1998, 17, 2.

Bull. Chem. Soc. Ethiop. 2011, 25(3) 
33. Correl, D.L. J. Environ. Quality 1988, 27, 261.

34. Flores-Laureano, J.S.; Navar, J. J. Environ. Quality 2002, 31, 1256.

35. Acquah, P. Technical Report, UNIDO/GEF GOG-LME Project, Accra; 1998; p 1.

36. Campolo, M.; Andreussi, P.; Soldati, A. Water Res. 2002, 36, 2673.

37. Chen, Z.-S. in: Biogeochemistry of Trace Metals, Adriano, D.C. (Ed.), Lewis Publishers: Boca Raton, Florida, USA; 1992; p 513.

38. World Health Organization (WHO). Environmental Health Criteria 135: CadmiumEnvironmental Aspects, World Health Organization: Geneva; 1992; p 156.

39. Yuan, Y. Environ. Protection Sci. 1993, 19, 70.

40. Bolann, B.J.; Rahil-Khazen, R.; Henriksen, H.; Isrenn, R.; Ulrik, R.J. Scand. J. Clin. Lab. Invest. 2007, 67, 353.

41. Soylak, M.; Tuzen, M. J. Hazard. Mater. 2008, 152, 656.

42. Ensafi, A.A.; Shiraz, A.Z. J. Hazard. Mater. 2008, 150, 554.

43. Shokrollahi, A.; Ghaedi, M.; Niband, M.S.; Rajabi, H.R. J. Hazard. Mater. 2008, 151, 642.

44. Gad, S.C. Sci. Total Environ. 1989, 86, 149.

45. Ogbonaya, C. Environ. Res. J. 2008, 2, 222.

46. Franson, M.A.H. Standard Methods for the Examination of Water and Wastewater, APHA: Washington DC; 1998; pp 1-45.

47. Rijs, G.B.J. Het toepassen van helofytenfilters bij de zuivering van kleinschalige afvalwaterlozingen; het einde. Studiedag Individuele Behandeling van Afvalwater, Van Hall Instituut: Leeuwarden; 1994; pp 1-8.

48. Central Pollution Control Board (CPCB) Water Quality Criteria, CPCB, India, Available at: http://www.cpcb..in/Watdata2002/criteria.htm.; 2005, p 1; Accessed on 18th March 2010.

49. Federal Environmental Protection Agency (FEPA) Effluent limit for discharge into surface water, Regulation (S. I. 8). No 42, Vol 78, Lagos, Nigeria; 1991; p 1.

50. Canadian Council of Ministers of Environmental (CCME) Canadian Environmental Quality Guidelines, CCME: Winnipeg, MB; 1999; $\mathrm{p} 1$.

51. Flemish Government (FG) Besluit van de Vlaamse Regering van 1 junn 1995 houdende vaststelling van het Vlaamse Reglement betreffende de milieuvergunningVlarem, zoals gewijzigd big gesluit van 17 juli 2000, Belgisch Staatsblad, 2000.

52. United State Environmental Protection Agency (USEPA) National recommended water quality criteria - Correction: EPA 822/Z-99-001, USEPA: Washington DC.; 1999; p 1.

53. Standard Organisation of Nigeria (SON) Nigerian Standard for Drinking Water Quality, Standard Organisation of Nigeria: Lagos, Nigeria; 2007, p 1.

54. Van der Leeden, F., Troise, F.L., Todd, D.K. The Water Encyclopedia, Lewis Publishers: Chelsea; 1990; $\mathrm{p} 1$. 